\title{
REGRESI KOMPONEN UTAMA ROBUST S-ESTIMATOR UNTUK ANALISIS PENGARUH JUMLAH PENGANGGURAN DI JAWA TENGAH
}

\author{
Jeffri Nelwin J. O. Siburian ${ }^{1}$, Rita Rahmawati ${ }^{2}$, Abdul Hoyyi ${ }^{3}$ \\ ${ }^{1,2,3}$ Departemen Statistika FSM Universitas Diponegoro \\ ritarahmawati@gmail.com
}

\begin{abstract}
Robust principal component regression s-estimator is principal component regression that applies robust approach method at principal component analysis and s-estimator at principal component regression analysis. The aim of robust principal component regression sestimator is to overcome multicollinearity problems in multiple linier regression Ordinary Least Square (OLS) and to overcome outlier problems in principal component regression so get the most effective model. Minimum Volume Ellipsoid (MVE) is one of the robust approach methods that applied when doing principal component analysis and S-Estimator is one of the estimation methods that applied when doing principal component regression analysis. The case in this study is the factors that influence the Number of Unemployment in Central Java in 2017. The model that provides the most effective result to handling multicolliniearity and ouliers in the case study Number of Unemployment in Central Java in 2017 is using robust principal component regression MVE-(S-Estimator) with Adjusted $\mathrm{R}^{2}$ value of 0.9615 and $\mathrm{RSE}$ value of 0.4073 .
\end{abstract}

Keywords: Robust Principal Component Regression S-Estimator, Multicollinearity, Outliers, Minimum Volume Ellipsoid (MVE), Number of Unemployment.

\section{PENDAHULUAN}

Pengangguran merupakan salah satu masalah di dalam suatu negara yang selalu menjadi pusat perhatian pemerintah. Menurut BPS (2018), pengangguran terbuka merupakan penduduk yang telah masuk dalam angkatan kerja tetapi tidak memiliki pekerjaan dan sedang mencari pekerjaan, mempersiapkan usaha, serta sudah memiliki pekerjaan tetapi belum mulai bekerja. Faktor-faktor yang diduga mempengaruhi jumlah pengangguran di Jawa Tengah adalah jumlah penduduk miskin, Indeks Pembangunan Manusia (IPM), rata-rata lama sekolah, Angka Partisipasi Sekolah (APS), Angka Partisipasi Murni (APM), dan jumlah penduduk.

Studi awal penelitian ini menggunakan regresi linier berganda dengan estimasi parameter Metode Kuadrat Terkecil (MKT), dalam proses analisis data jumlah pengangguran beserta faktor-faktornya terjadi pelanggaran asumsi non multikolinieritas. Pelanggaran asumsi tersebut menyebabkan adanya hubungan linear antar beberapa atau semua variabel independen dari model regresi (Gujarati, 2004). Menurut Montgomery dan Peck (2012), masalah multikolinieritas dapat diatasi dengan menggunakan regresi komponen utama. Regresi komponen utama merupakan teknik analisis regresi yang dikombinasikan dengan analisis komponen utama. Pada tahap analisis komponen utama ditemukan kembali masalah baru yaitu terdapat data yang mengandung pencilan, sehingga pada tahap ini akan digunakan analisis komponen utama robust dengan pendekatan Minimum Volume Ellipsoid (MVE).

Terdapatnya outlier mengakibatkan metode Ordinary Least Square (OLS) memiliki estimasi koefisien garis regresi yang diperoleh menjadi tidak tepat, artinya nilai estimator dari parameter menjadi bias. Menurut Draper dan Smith (1992) menggunaan regresi robust 
memiliki kelebihan dibandingkan dengan metode OLS, yaitu kurang peka terhadap penyimpangan-penyimpangan yang sering terjadi dari asumsi ideal. Menurut Chen (2002), regresi robust terdiri dari 5 metode estimasi, yaitu M-estimator, Least Median Square (LMS)-estimator, Least Trimmed Square (LTS)-estimator, S-estimator, dan MM-estimator. Kelima metode tersebut memiliki kelebihan dan kelemahan masing-masing. Dilihat dari nilai breakdown point-nya, $S$-estimator merupakan estimasi robust yang memiliki nilai breakdown point paling tinggi. Proses analisis Regresi Komponen Utama akan menghasilkan beberapa model dan akan ditentukan model terbaik.

\section{TINJAUAN PUSTAKA}

\subsection{Analisis Regresi Linier Berganda}

Menurut Montgomery dan Peck (2012), Model regresi berganda dinyatakan dalam bentuk persamaan :

$$
y_{i}=\beta_{0}+\beta_{1} x_{i 1}+\beta_{2} x_{i 2}+\cdots+\beta_{k} x_{i k}+\varepsilon_{i}
$$

Jika ditulis dalam bentuk matriks, persamaan (1) dapat ditulis sebagai berikut :

$$
\begin{gathered}
\boldsymbol{y}=\boldsymbol{X} \boldsymbol{\beta}+\boldsymbol{\varepsilon} \\
\mathbf{y}=\left[\begin{array}{c}
\mathrm{y}_{1} \\
y_{2} \\
\vdots \\
y_{\mathrm{n}}
\end{array}\right] \quad ; \boldsymbol{X}=\left[\begin{array}{ccccc}
1 & x_{11} & x_{12} & \cdots & x_{1 k} \\
1 & x_{21} & x_{22} & \cdots & x_{2 k} \\
\vdots & \vdots & \vdots & \ddots & \vdots \\
1 & x_{n 1} & x_{n 2} & \cdots & x_{n k}
\end{array}\right] \quad ; \quad \boldsymbol{\beta}=\left[\begin{array}{c}
\beta_{0} \\
\beta_{1} \\
\vdots \\
\beta_{k}
\end{array}\right] \quad ; \boldsymbol{\varepsilon}=\left[\begin{array}{c}
\varepsilon_{1} \\
\varepsilon_{2} \\
\vdots \\
\varepsilon_{\mathrm{n}}
\end{array}\right]
\end{gathered}
$$

\subsubsection{Estimasi Parameter Model Regresi Linier Berganda}

Metode yang digunakan untuk mengestimasi parameter model regresi adalah dengan meminimumkan jumlah kuadrat residual atau yang sering dikenal dengan Metode Kuadrat Terkecil (MKT) (Gujarati, 2004).

$$
J=\sum_{i=1}^{n} \varepsilon_{i}^{2}=\varepsilon^{\prime} \varepsilon=(y-X \beta)^{\prime}(y-X \beta)
$$

Untuk mendapatkan estimator kuadrat terkecil $(\widehat{\boldsymbol{\beta}})$ yang meminimumkan $\boldsymbol{J}$ disyaratkan bahwa $\left.\frac{\partial \boldsymbol{J}}{\partial \boldsymbol{\beta}}\right|_{\boldsymbol{\beta}=\widehat{\boldsymbol{\beta}}}=0$. Turunan pertama dari $\boldsymbol{J}$ terhadap $\widehat{\boldsymbol{\beta}}$ adalah :

$$
\left.\frac{\partial J}{\partial \boldsymbol{\beta}}\right|_{\boldsymbol{\beta}=\widehat{\boldsymbol{\beta}}}=-2 \boldsymbol{X}^{\prime} \boldsymbol{y}+2 \boldsymbol{X}^{\prime} \boldsymbol{X} \widehat{\boldsymbol{\beta}}
$$

karena, $\left.\frac{\partial \boldsymbol{L}}{\partial \boldsymbol{\beta}}\right|_{\boldsymbol{\beta}=\widehat{\boldsymbol{\beta}}}=0$, maka

$$
\begin{aligned}
-2 \boldsymbol{X}^{\prime} \boldsymbol{y}+2 \boldsymbol{X}^{\prime} \boldsymbol{X} \widehat{\boldsymbol{\beta}} & =0 \\
\widehat{\boldsymbol{\beta}} & =\left(\boldsymbol{X}^{\prime} \boldsymbol{X}\right)^{-\mathbf{1}} \boldsymbol{X}^{\prime} \boldsymbol{y}
\end{aligned}
$$

Menurut Kurtner et al. (2005), dalam mengestimasi parameter model regresi perbedaan satuan akan menyebabkan koefisien tidak bisa dibandingkan. Oleh karena itu pada penelitian ini akan dilakukan pembakuan data dengan rumus berikut:

$$
Y_{i}^{*}=\left(\frac{Y_{i}-\bar{Y}}{S_{Y}}\right) ; X_{j i}^{*}=\left(\frac{X_{j i}-\bar{X}_{j}}{S_{j}}\right)
$$

dimana: $S_{Y}=\sqrt{\frac{\sum_{i=1}^{n}\left(Y_{i}-\bar{Y}\right)^{2}}{n-1}} ; S_{j}=\sqrt{\frac{\sum_{i=1}^{n}\left(X_{j i}-\bar{X}_{j}\right)^{2}}{n-1}}$

dengan: $\quad Y_{i}^{*}$ : variabel dependen dalam bentuk standar

$X_{j i}{ }^{*}$ : variabel independen dalam bentuk standar

$\bar{Y}$ : rata-rata variabel dependen

$\bar{X}_{j}$ : rata-rata variabel independen 
$S_{Y}:$ standar deviasi variabel dependen

$S_{j} \quad$ : standar deviasi variabel independen

Sehingga diperoleh model regresi standar sebagai berikut:

$$
Y_{i}^{*}=\beta_{1}^{*} X_{1 i}^{*}+\beta_{2}^{*} X_{2 i}^{*}+\cdots+\beta_{k}^{*} X_{k i}^{*}+\varepsilon_{i}^{*}
$$

\subsubsection{Uji Hipotesis dalam Regresi Linier Berganda}

\section{a. Uji Signifikansi Kecocokan Model Regresi}

Uji signifikansi regresi digunakan untuk menguji apakah ada hubungan linier antara variabel respon $y$ dan variabel prediktor $x_{1}, x_{2}, \ldots, x_{k}$ secara bersama-sama (Montgomery dan Runger, 2011). Berikut langkah-langkahnya :

1. Hipotesis

$\mathrm{H}_{0}: \beta_{1}=\beta_{2}=\ldots=\beta_{\mathrm{k}}=0$

$\mathrm{H}_{1}$ : terdapat $\beta_{\mathrm{j}} \neq 0$, dengan $\mathrm{j}=1,2, \ldots, \mathrm{k}$

2. Statistik uji

$$
F_{\text {hitung }}=\frac{J K R / k}{J K S /(n-k-1)}=\frac{\mathrm{MSR}}{\mathrm{MSE}}
$$

3. Kriteria uji

$\mathrm{H}_{0}$ ditolak jika $F_{\text {hitung }}>F_{(\alpha, k, n-k-1)}$ atau $p$-value $<\alpha$

\section{b. Uji Koefisien Regresi secara Individual}

Uji koefisien regresi secara individual digunakan untuk menguji ada tidaknya pengaruh yang signifikan antara masing - masing variabel prediktor terhadap model regresi linier, berikut langkah-langkah pengujiannya :

1. Hipotesis

$$
\begin{aligned}
& \mathrm{H}_{0}: \beta_{\mathrm{j}}=0 \\
& \mathrm{H}_{1}: \beta_{\mathrm{j}} \neq 0
\end{aligned}
$$

2. Statistik uji

$$
t_{\text {hitung }}=\frac{\widehat{\beta}_{j}}{\operatorname{Se}\left(\widehat{\beta}_{j}\right)} ; \text { dengan } \operatorname{Se}\left(\hat{\beta}_{j}\right)=\sqrt{\widehat{\sigma}^{2} \mathrm{C}_{\mathrm{jj}}}
$$

3. Kriteria uji

$$
\mathrm{H}_{0} \text { ditolak jika }\left|t_{\text {hitung }}\right|>t_{(\alpha / 2, n-k-1)} \text { atau } p \text {-value }<\alpha
$$

\subsubsection{Goodness Of Fit (Ukuran Kecocokan Model)}

\section{a. Koefisien Determinasi yang disesuaikan (Adjusted $\boldsymbol{R}^{\mathbf{2}}$ )}

Menurut Montgomery dan Peck (2012), koefisien determinasi merupakan suatu nilai atau ukuran yang dapat digunakan untuk menilai kecocokan dari suatu model regresi.

$$
R^{2}{ }_{A d j, k}=1-\frac{J K S /(n-k-1)}{J K T /(n-1)}
$$

\section{b. RSE (Mean Square Error)}

Residual Standard Error (RSE) adalah estimasi simpangan baku (standard deviation) dari $\varepsilon$.

$$
R S E=\sqrt{\frac{\sum_{i=1}^{n}\left(Y_{i}-\hat{Y}_{i}\right)^{2}}{n-k-1}}=\sqrt{M S E}
$$

\subsection{Multikolinieritas}

Menurut Gujarati (2004), multikolinieritas merupakan adanya hubungan linear antara beberapa atau semua variabel independen dari model regresi (Gujarati, 2004). Ada beberapa cara yang digunakan untuk mendeteksi adanya multikolinieritas yaitu sebagai berikut: 
a. Melihat nilai koefisien determinasi $\left(R^{2}\right)$

b. Melihat korelasi antar variabel independen

c. Melihat nilai Variance Inflation Factor (VIF)

Menurut Montgomery dan Peck (2012), selain menggunakan cara-cara tersebut multikolinieritas dapat juga ditangani dengan menggunakan analisis regresi ridge dan regresi komponen utama.

\subsection{Pencilan}

Menurut Neter et al. (1988), pencilan merupakan suatu pengamatan yang ekstrim. Salah satu metode yang dapat digunakan untuk mendeteksi pencilan adalah DFFITS

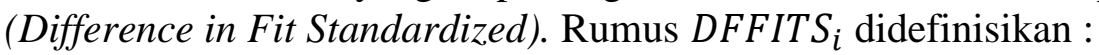

$$
\left(\text { DFFITS }_{i}\right)=t_{i}\left(\frac{h_{i i}}{1-h_{i i}}\right)^{\frac{1}{2}}
$$

dimana $t_{i}$ adalah studentized deleted residual untuk kasus ke- $i$ dengan rumus:

$$
t_{i}=e_{i} \sqrt{\frac{n-p-1}{s S_{E}\left(1-h_{i i}\right)-e_{i}^{2}}}
$$

Suatu data disebut pencilan jika nilai $\mid$ DFFITS $\mid>2 \sqrt{p / n}$ untuk gugus data yang berukuran besar, dengan $p=k+1$, dan $n$ adalah banyaknya observasi (Montgomery dan Peck, 2012).

\subsection{Analisis Komponen Utama}

Menurut Johnson dan Winchern (2007), komponen utama merupakan kombinasi linier yang didasarkan pada skala pengukuran variabel random $\mathrm{k}\left(\mathrm{X}_{1}, \mathrm{X}_{2}, \ldots, \mathrm{X}_{\mathrm{k}}\right)$. Kemudian dari variabel random tersebut akan dibentuk suatu variabel yang baru $U$ yang akan menjadi komponen utama. Bentuk dari kombinasi linier tersebut sabagai berikut:

$$
\begin{aligned}
& \mathrm{U}_{1}=\mathbf{a} \mathbf{1}^{\prime} \mathbf{X}=\mathrm{a}_{11} \mathrm{X}_{1}+\mathrm{a}_{12} \mathrm{X}_{2}+\ldots+\mathrm{a}_{1 \mathrm{k}} \mathrm{X}_{\mathrm{k}} \\
& \mathrm{U}_{2}=\mathbf{a} \mathbf{2}^{\prime} \mathbf{X}=\mathrm{a}_{21} \mathrm{X}_{1}+\mathrm{a}_{22} \mathrm{X}_{2}+\ldots+\mathrm{a}_{2 \mathrm{k}} \mathrm{X}_{\mathrm{k}} \\
& \vdots \\
& \mathrm{U}_{\mathrm{k}}=\mathbf{a}_{\mathbf{k}}, \mathbf{X}=\mathrm{a}_{\mathrm{k} 1} \mathrm{X}_{1}+\mathrm{a}_{\mathrm{k} 2} \mathrm{X}_{2}+\ldots+\mathrm{a}_{\mathrm{kk}} \mathrm{X}_{\mathrm{k}}
\end{aligned}
$$

dengan : $\operatorname{Cov}\left(\mathrm{U}_{\mathrm{j}}, \mathrm{U}_{\mathrm{l}}\right)=\mathbf{a}_{\mathbf{j}} \mathbf{} \boldsymbol{\Sigma}$ al dan $\operatorname{Var}\left(\mathrm{U}_{\mathrm{j}}\right)=\mathbf{a} \mathbf{j}^{\prime} \boldsymbol{\Sigma} \mathbf{a}_{\mathbf{j}}$ di mana $\mathrm{j}=1,2, \ldots, \mathrm{k}$

proporsi dari total varians ke- $j=\frac{\lambda_{j}}{\lambda_{1}+\lambda_{2}+\cdots+\lambda_{k}} \times 100 \% ; j=1,2, \ldots, k$

Komponen utama juga dapat diperoleh dari variabel yang distandarkan, sehingga akan diperoleh komponen utama yang dibentuk sebagai kombinasi linier dari variabel yang distandarkan yaitu $\mathrm{Z}_{1}, \mathrm{Z}_{2}, \ldots, \mathrm{Z}_{\mathrm{k}}$ adalah:

$$
\begin{aligned}
& \mathrm{U}_{1}=\mathbf{a}_{1}^{\prime} \mathbf{Z}=\mathrm{a}_{11} Z_{1}+\mathrm{a}_{12} Z_{2}+\ldots+\mathrm{a}_{1 \mathrm{k}} Z_{\mathrm{k}} \\
& \mathrm{U}_{2}=\mathbf{a} \mathbf{2}^{\prime} \mathbf{Z}=\mathrm{a}_{21} Z_{1}+\mathrm{a}_{22} Z_{2}+\ldots+\mathrm{a}_{2 \mathrm{k}} Z_{\mathrm{k}} \\
& \vdots \\
& \mathrm{U}_{\mathrm{k}}=\mathbf{a}_{\mathbf{k}}{ }^{\prime} \mathbf{Z}=\mathrm{a}_{\mathrm{k} 1} \mathrm{Z}_{1}+\mathrm{a}_{\mathrm{k} 2} \mathrm{Z}_{2}+\ldots+\mathrm{a}_{\mathrm{kk}} Z_{\mathrm{k}}
\end{aligned}
$$

Ada beberapa cara untuk menentukan seberapa banyak jumlah komponen yang digunakan yaitu:

a. Memilih komponen-komponen utama yang mempunyai kumulatif proporsi keragaman total $75 \%$.

b. Memilih komponen utama yang mempunyai eigenvalue lebih besar dari satu.

c. Melihat scree plot di mana scree plot tersebut merupakan plot antara $\lambda_{j}$ dan $\mathrm{j}$. 


\subsection{Regresi Komponen Utama}

Setelah melakukan analisis komponen utama, selanjutnya melakukan regresi komponen utama dengan cara meregresikan skor komponen utama terhadap variabel dependen menggunakan Ordinary Least Square (OLS). Untuk bentuk persamaan regresinya sebagai berikut:

$$
Y_{i}=\alpha_{0}+\alpha_{1} U_{1 i}+\alpha_{2} U_{2 i}+\cdots+\alpha_{m} U_{m i}+\gamma_{i}
$$

Jika ditulis dalam bentuk matriks, persamaan (15) dapat ditulis sebagai berikut :

$$
\begin{gathered}
\mathbf{y}=\boldsymbol{U} \boldsymbol{\alpha}+\boldsymbol{\gamma} \\
\mathbf{y}=\left[\begin{array}{c}
Y_{1} \\
Y_{2} \\
\vdots \\
Y_{n}
\end{array}\right] ; \mathbf{U}=\left[\begin{array}{ccccc}
1 & U_{11} & U_{21} & \cdots & U_{m 1} \\
1 & U_{12} & U_{22} & \cdots & U_{m 2} \\
\vdots & \vdots & \vdots & \ddots & \vdots \\
1 & U_{1 n} & U_{2 n} & \ldots & U_{m n}
\end{array}\right] ; \boldsymbol{\alpha}=\left[\begin{array}{c}
\alpha_{0} \\
\alpha_{1} \\
\alpha_{2} \\
\vdots \\
\alpha_{m}
\end{array}\right] ; \boldsymbol{\gamma}=\left[\begin{array}{c}
\gamma_{1} \\
\gamma_{2} \\
\vdots \\
\gamma_{n}
\end{array}\right]
\end{gathered}
$$

Parameter $\widehat{\boldsymbol{\alpha}}$ dapat diestimasi menggunakan metode Ordinary Least Squares (OLS) menggunakan rumus:

$$
\widehat{\boldsymbol{\alpha}}=\left(\boldsymbol{U}^{\prime} \boldsymbol{U}\right)^{-\mathbf{1}}\left(\boldsymbol{U}^{\prime} \boldsymbol{y}\right)
$$

Seperti halnya regresi pada umumnya, akan dilakukan uji signifikansi pada model regresi komponen utama baik itu signifikansi pada model ataupun signifikansi secara individu. Untuk hipotesis yang digunakan dalam signifikansi model yaitu:

\section{a. Uji Signifikansi Kecocokan Model Regresi}

Uji signifikansi regresi digunakan untuk menguji apakah ada hubungan linier antara variabel respon $y$ dan variabel prediktor $x_{1}, x_{2}, \ldots, x_{k}$ secara bersama-sama (Montgomery dan Runger, 2011). Berikut langkah-langkahnya :

1. Hipotesis

$$
\begin{aligned}
& H_{0}: \alpha_{1}=\alpha_{2}=\ldots=\alpha_{m} \\
& H_{1}: \text { terdapat } \alpha_{j} \neq 0, \text { dengan } j=1,2, \ldots, m
\end{aligned}
$$

2. Statistik uji

$$
F_{\text {hitung }}=\frac{J K R / k}{J K S /(n-m-1)}=\frac{\mathrm{MSR}}{\mathrm{MSE}}
$$

3. Kriteria uji

$\mathrm{H}_{0}$ ditolak jika $F_{\text {hitung }}>F_{(\alpha, k, n-m-1)}$ atau $p$-value $<\alpha$

\section{b. Uji Koefisien Regresi secara Individual}

Uji koefisien regresi secara individual digunakan untuk menguji ada tidaknya pengaruh yang signifikan antara masing - masing variabel prediktor terhadap model regresi linier, berikut langkah-langkah pengujiannya :

1. Hipotesis

$$
\begin{aligned}
& H_{0}: \alpha_{j}=0 \\
& H_{1}: \alpha_{j} \neq 0
\end{aligned}
$$

2. Statistik uji

$$
t_{\text {hitung }}=\frac{\widehat{\beta}_{j}}{\operatorname{Se}\left(\widehat{\beta}_{j}\right)} ; \text { dengan } \operatorname{Se}\left(\hat{\beta}_{j}\right)=\sqrt{\widehat{\sigma}^{2} \mathrm{C}_{\mathrm{jj}}}
$$

3. Kriteria uji

$\mathrm{H}_{0}$ ditolak jika $\left|t_{\text {hitung }}\right|>t_{(\alpha / 2, n-m-1)}$ atau $p$-value $<\alpha$

\subsection{Metode Minimum Volume Ellipsoid (MVE)}

Minimum Volume Ellipsoid (MVE) pertama kali diperkenalkan oleh Rousseuw merupakan penaksir robust. Karena dalam mencari solusi eksak dalam menyelesaikan 
masalah pada MVE ini dapat dikatakan sulit, maka alternatif lain adalah melalui pendekatan algoritma resampling yang disebut juga algoritma $(k+1)$ subset. Berikut merupakan langkah-langkah algoritma resampling untuk mendapatkan elipsoid dengan volume minimum:

1. Bentuk subsampel yang mengandung $k+1$ pengamatan yang disimbolkan dengan indeks $j=\left\{i_{1}, i_{2}, \ldots . i_{k+1}\right\} \subset\{1,2, \ldots n\}$

2. Menentukan rata-rata (mean) sampel dengan rumus:

$$
T_{j}=\bar{x}_{J}=\frac{1}{k+1} \sum_{i=1}^{k+1} x_{i j}
$$

Selanjutnya ditentukan matriks kovarian dari sampel dengan rumus:

$$
S_{j}=\frac{1}{k} \sum_{i=1}^{k+1}\left(X_{i}-\bar{X}\right)^{\prime}\left(X_{i}-\bar{X}\right)
$$

3. Menghitung jarak Mahalanobis untuk semua pengamatan dengan rumus:

$$
D_{j}^{2}=\left[\left(\boldsymbol{X}_{i}-\bar{X}\right)^{\prime} \boldsymbol{S}^{-1}\left(\boldsymbol{X}_{\boldsymbol{i}}-\overline{\boldsymbol{X}}\right)\right]_{h: n}
$$

4. Sebagai penentu yang sangat penting dalam MVE adalah volume ellipsoid yang proporsional dengan nilai:

$$
V_{J}=\left(\frac{D_{J}}{C}\right)^{k} \sqrt{\operatorname{det}\left(S_{J}\right)}
$$

5. Setelah selesai langkah keempat, maka ulangi langkah pertama sampai keempat di atas untuk subsampel kedua. Proses diulang sampai sebanyak $\left(\begin{array}{c}n \\ k+1\end{array}\right)$ subsampel.

6. Pilih subsampel yang elipsoidnya memiliki volume paling minimum.

7. Hitung $\boldsymbol{T}(\boldsymbol{X})$ dan $\boldsymbol{S}(\boldsymbol{X})=c^{2}(n, k)\left(X_{k, \alpha}^{2}\right)^{-1} D_{j}^{2} \boldsymbol{S}_{\boldsymbol{j}}$ dari $V_{j}$ yang akan digunakan sebagai estimasi mean dan matriks varians dan kovarians, dengan $c^{2}(n, k)=\left[1+\frac{15}{n-k}\right]^{2}$ yang disebut correction term .

\subsection{Metode $S$-Estimator}

Menurut Stuart (2011), salah satu cara yang digunakan untuk mengukur kekekaran suatu estimator adalah dengan breakdown point. Breakdown point merupakan proporsi minimal dari banyaknya outlier dibandingkan seluruh data pengamatan. S-estimator didefinisikan dengan:

$$
\widehat{\boldsymbol{\beta}}=\min _{\beta}\left(e_{1}(\boldsymbol{\beta}), e_{2}(\boldsymbol{\beta}) \ldots, e_{n}(\boldsymbol{\beta})\right)
$$

$e_{i}$ merupakan residual ke- $i$ dari $\boldsymbol{\beta}$ dan $s\left(e_{1}, e_{2} \ldots, e_{n}\right)$ didefinisikan sebagai solusi dari:

$$
\frac{1}{n} \sum_{i=1}^{n} \rho\left(\frac{e_{i}}{s}\right)=\frac{1}{n} \sum_{i=1}^{n} \rho\left(\frac{y_{i}-\sum_{j=0}^{k} x_{i j} \beta_{j}}{s}\right)=K
$$

dengan $K$ merupakan suatu konstanta yang didefinisikan sebagai $K=0,1995$, untuk mencapai breakdown point 50\% (Rousseeuw dan Yohai, 1984), sedangkan $s$ merupakan skala estimasi robust. Menurut Maronna, Martin dan Yohai (2006), nilai $s$ untuk iterasi kedua dan seterusnya dapat diperoleh dengan:

$$
s=\sqrt{\frac{1}{n K} \sum_{i=1}^{n} w_{i} e_{i}^{2}}
$$

Pembobot $w_{i}=w\left(u_{i}\right)=\frac{\rho\left(u_{i}\right)}{u_{i}{ }^{2}}$ untuk iterasi kedua dan seterusnya. Untuk iterasi pertama menggunakan:

$$
s=\frac{M A D}{0,6745}=\frac{\text { median } \mid e_{i}-\text { median }\left(e_{i}\right) \mid}{0,6745}
$$


dengan menurunkan parsial pertama dari $\rho$ terhadap $\beta_{j}(j=0,1, \ldots, k)$ disamakan dengan 0 seperti berikut:

$$
\sum_{i=1}^{n} x_{i j} \psi\left(\frac{y_{i}-\sum_{j=0}^{k} x_{i j} \beta_{j}}{s}\right)=0, \quad j=0,1, \ldots, k
$$

dimana $\psi=\rho^{\prime}$ dan $x_{i j}$ adalah pengamatan ke- $i$ pada parameter ke- $j$ dan $x_{i 0}=1$.

Draper dan Smith (1998) memberikan solusi pada persamaan di atas dengan mendefinisikan fungsi pembobot:

$$
w\left(u_{i}\right)=\frac{\psi\left(\frac{y_{i}-\sum_{j=0}^{k} x_{i j} \beta_{j}}{s}\right)}{\left(\frac{y_{i}-\sum_{j=0}^{k} x_{i j} \beta_{j}}{s}\right)}
$$

dan $w_{i}=w\left(u_{i}\right)$. Kemudian estimasi pada turunan parsial pertama dari $\rho$ terhadap $\beta_{j}$ dapat ditulis:

$$
\sum_{i=1}^{n} x_{i j} w_{i}\left(y_{i}-\sum_{j=0}^{k} x_{i j} \beta_{j}\right)=0 \quad, j=0,1, \ldots, k
$$

Persamaan (30) diselesaikan dengan Iteratively Reweighted Least Square (IRLS). Pada notasi matrik, persamaan (30) dapat ditulis:

$$
\widehat{\boldsymbol{\beta}}_{\boldsymbol{j}}=\left(\boldsymbol{X}^{\prime} \boldsymbol{W} \boldsymbol{X}\right)^{-\mathbf{1}} \boldsymbol{X}^{\prime} \boldsymbol{W} \mathbf{y}
$$

Iterasi akan berhenti jika $\widehat{\boldsymbol{\beta}}_{\boldsymbol{j}}$ konvergen yaitu selisih nilai $\widehat{\boldsymbol{\beta}}_{\boldsymbol{j}}^{(\boldsymbol{m}+\mathbf{1})}$ dan $\widehat{\boldsymbol{\beta}}_{\boldsymbol{j}}^{(\boldsymbol{m})}$ mendekati 0

\subsection{Pengangguran}

Menurut BPS (2018), pengangguran terbuka merupakan jumlah orang yang masuk dalam angkatan kerja (usia 15 tahun ke atas) yang sedang mencari pekerjaan dan belum mendapatkannya. Faktor-faktor yang mungkin mempengaruhi jumlah pengangguran yaitu jumlah penduduk miskin, Indeks Pembangunan Manusia (IPM), rata-rata lama sekolah, Angka Partisipasi Sekolah (APS), Angka Partisipasi Murni (APM), dan jumlah penduduk.

\section{METODOLOGI PENELITIAN}

\subsection{Jenis dan Sumber Data}

Data yang digunakan dalam penelitian ini adalah data sekunder, yang diperoleh dari Badan Pusat Statistik Provinsi Jawa Tengah melalui publikasi Jawa Tengah Dalam Angka 2018. Objek penelitiannya adalah jumlah pengangguran, jumlah penduduk miskin, Indeks Pembangunan Manusia (IPM), rata-rata lama sekolah, Angka Partisipasi Sekolah (APS) untuk umur 16-18 tahun, Angka Partisipasi Murni (APM) untuk umur 16-18 tahun, dan jumlah penduduk di setiap kabupaten/kota di Provinsi Jawa Tengah tahun 2017.

\subsection{Variabel Penelitian}

Variabel yang digunakan dalam penelitian ini adalah:

$y$ : Jumlah pengangguran

$x_{1}$ : Jumlah penduduk miskin

$x_{2}$ : Indeks Pembangunan Manusia

$x_{3}$ : Rata-rata lama sekolah

$x_{4}$ : Angka Partisipasi Sekolah untuk umur 16-18 tahun

$x_{5}$ : Angka Partisipasi Murni untuk umur 16-18 tahun

$x_{6}$ : Jumlah penduduk 


\subsection{Langkah-Langkah Penelitian}

1. Mengumpulkan data dan menentukan variabel dependen dan variabel independen.

2. Mempersiapkan software $R$ 3.4.3., dan menginstal beberapa package dalam software R 3.4.3 diantaranya yaitu lmtest, car, MASS, dan robustbase.

3. Memasukkan data ke dalam software R 3.4.3.

4. Melakukan analisis deskriptif dan standarisasi terhadap data penelitian.

5. Melakukan analisis regresi linier berganda dengan metode OLS.

6. Melakukan pemeriksaan asumsi non-multikolinieritas dengan cara melihat nilai VIF dan nilai koefisien korelasi pearson antar variabel independen.

7. Mendeteksi adanya outlier pada variabel independen menggunakan jarak mahalanobis.

8. Melakukan analisis komponen utama klasik dan analisis komponen utama robust terhadap variabel independen.

9. Meregresikan komponen-komponen utama terpilih dari analisis komponen utama klasik dan analisis komponen utama robust dengan variabel dependen menggunakan metode OLS.

10. Melakukan uji signifikansi model regresi melalui uji $\mathrm{F}$ dan uji koefisien regresi secara individu melalui uji t.

11. Melakukan deteksi multikolinieritas dan diperoleh hasil bahwa masalah multikolinieritas sudah teratasi.

12. Menghitung nilai Adjusted $\mathrm{R}^{2}$ dan nilai RSE.

13. Mendeteksi adanya outlier pada dua buah model yang diperoleh dari langkah 12 menggunakan metode DFFITS.

14. Jika ada outlier, maka lakukan analisis regresi komponen utama robust, yaitu meregresikan komponen-komponen utama terpilih dengan variabel dependen menggunakan metode $S$-estimator.

15. Melakukan uji signifikansi model regresi melalui uji $\mathrm{F}$ dan uji koefisien regresi secara individu melalui uji t.

16. Menghitung nilai Adjusted $\mathrm{R}^{2}$ dan nilai RSE.

17. Mengembalikan persamaan regresi ke bentuk variabel asal.

18. Menarik kesimpulan

\section{HASIL DAN PEMBAHASAN}

\subsection{Regresi Linier Berganda}

Pada awal penelitian dilakukan analisis regresi linier berganda dengan estimasi parameter menggunakan Metode Kuadrat Terkecil.

\subsubsection{Estimasi Parameter Regresi}

Dari hasil output didapatkan model regresi linier berganda sebagai berikut: $\widehat{\mathrm{Q}}=0,18606 \mathrm{Z}_{1}-0,32160 \mathrm{Z}_{2}+0,62781 \mathrm{Z}_{3}-0,22919 \mathrm{Z}_{4}-0,00012 \mathrm{Z}_{5}+$

Keterangan:

$$
0,75035 \mathrm{Z}_{6}
$$

$\widehat{Q}$ : Data Jumlah Pengangguran yang Distandarisasi

$\mathrm{Z}_{1}$ : Data Jumlah Penduduk Miskin yang Distandarisasi

$\mathrm{Z}_{2}$ : Data Indeks Pembangunan Manusia (IPM) yang Distandarisasi

$\mathrm{Z}_{3}$ : Data Rata-rata Lama Sekolah yang Distandarisasi

$\mathrm{Z}_{4}$ : Data Angka Partisipasi Sekolah (APS) yang Distandarisasi

$Z_{5}$ : Data Angka Partisipasi Murni (APM) yang Distandarisasi

$\mathrm{Z}_{6}$ : Data Jumlah Penduduk yang Distandarisasi 


\subsubsection{Uji Signifikansi dalam Regresi Linier Berganda}

a. Uji F

1. Hipotesis

$H_{0}: \beta_{1}=\beta_{2}=\beta_{3}=\beta_{4}=\beta_{5}=\beta_{6}=0$

$\mathrm{H}_{1}$ : terdapat $\beta_{\mathrm{j}} \neq 0, \mathrm{j}=1,2,3,4,5,6$

2. Taraf signifikansi

$\alpha=5 \%$

3. Statistik uji

$F_{\text {hitung }}=21,628240$

4. Kriteria uji

$\mathrm{H}_{0}$ ditolak jika $F_{\text {hitung }}>\left(F_{(5 \%, 6,29)}=2,432\right)$

5. Keputusan

$\mathrm{H}_{0}$ ditolak karena nilai $F_{\text {hitung }}=17,73>F_{(5 \%, 6,29)}=2,432$

6. Kesimpulan

Pada taraf signifikansi 5\% paling sedikit ada satu variabel independen (jumlah penduduk miskin, IPM, rata-rata lama sekolah, APS, APM, dan jumlah penduduk) yang ada hubungan dengan variabel dependen jumlah penganguran secara bersama-sama.

b. Uji Koefisien Regresi secara Individual (Uji t)

1. Hipotesis

$\mathrm{H}_{0}: \beta_{\mathrm{j}}=0$, dimana $\mathrm{j}=1,2,3,4,5,6$

$\mathrm{H}_{1}: \beta_{\mathrm{j}} \neq 0$, dimana $\mathrm{j}=1,2,3,4,5,6$

2. Taraf signifikansi

$\alpha=5 \%$

3. Statistik uji

Disajikan pada Tabel 2.

4. Kriteria uji

$\mathrm{H}_{0}$ ditolak jika $\left|t_{\text {hitung }}\right|>\left(t_{(2,5 \%, 29)}=2,045\right)$ atau $p$-value $<\alpha(0,05)$

5. Keputusan

Tabel 1. Tabel Uji t Regresi Linier Berganda

\begin{tabular}{cccll}
\hline Variabel & $\left|\mathbf{t}_{\mathbf{0}}\right|$ & $\boldsymbol{p}$-value & Keputusan & Kesimpulan \\
\hline $\mathrm{Z}_{1}$ & 1,006 & 0,322698 & $\mathrm{H}_{0}$ diterima & Tidak Signifikan \\
$\mathrm{Z}_{2}$ & 0,908 & 0,371548 & $\mathrm{H}_{0}$ diterima & Tidak Signifikan \\
$\mathrm{Z}_{3}$ & 1,786 & 0,084643 & $\mathrm{H}_{0}$ diterima & Tidak Signifikan \\
$\mathrm{Z}_{4}$ & 0,926 & 0,362209 & $\mathrm{H}_{0}$ diterima & Tidak Signifikan \\
$\mathrm{Z}_{5}$ & 0,001 & 0,999505 & $\mathrm{H}_{0}$ diterima & Tidak Signifikan \\
$\mathrm{Z}_{6}$ & 4,263 & 0,000195 & $\mathrm{H}_{0}$ ditolak & Signifikan \\
\hline
\end{tabular}

6. Kesimpulan

Pada taraf signifikansi 5\% koefisien parameter variabel yang berpengaruh signifikan terhadap jumlah pengangguran $(\mathrm{Q})$ adalah jumlah penduduk $\left(\mathrm{Z}_{6}\right)$.

\subsubsection{Goodness Of Fit}

Dalam penelitian ini, uji kecocokan model yang digunakan adalah nilai koefisien determinasi yang disesuaikan dan nilai RSE. Diperoleh nilai koefisien determinasi yang disesuaikan sebagai berikut:

$$
R^{2}{ }_{\text {Adj,k }}=0,7415
$$

Hal ini mengindikasikan besar pengaruh jumlah penduduk miskin, Indeks Pembangunan Manusia, rata-rata lama sekolah, Angka Partisipasi Sekolah untuk umur 16-18 tahun, Angka 
Partisipasi Murni untuk umur 16-18 tahun, dan jumlah penduduk terhadap jumlah pengangguran adalah $74,15 \%$. Sedangkan sisanya sebesar $25,85 \%$ jumlah pengangguran dipengaruhi model lain

Nilai RSE untuk regresi linier berganda menggunakan estimasi Metode Kuadrat Terkecil adalah sebagai berikut:

$$
\mathrm{RSE}=0,5011
$$

\subsection{Deteksi Multikolinieritas}

Tabel 2. Nilai VIF

\begin{tabular}{ccc}
\hline Variabel & VIF & Keterangan \\
\hline $\mathrm{Z}_{1}$ & 4,63012 & $\mathrm{VIF}<10$ \\
$\mathrm{Z}_{2}$ & 16,99603 & $\mathrm{VIF}>10$ \\
$\mathrm{Z}_{3}$ & 16,73693 & $\mathrm{VIF}>10$ \\
$\mathrm{Z}_{4}$ & 8,29703 & $\mathrm{VIF}<10$ \\
$\mathrm{Z}_{5}$ & 5,48171 & $\mathrm{VIF}<10$ \\
$\mathrm{Z}_{6}$ & 4,19507 & $\mathrm{VIF}<10$ \\
\hline
\end{tabular}

Dilihat dari Tabel 3, variabel IPM $\left(\mathrm{Z}_{2}\right)$ dan rata-rata lama sekolah $\left(\mathrm{Z}_{3}\right)$ mempunyai nilai VIF lebih besar dari 10 yang mengindikasikan adanya multikolinieritas dalam model regresi.

\subsection{Analisis Komponen Utama}

\subsubsection{Deteksi Outlier}

Dengan nilai $\chi_{(6 ; 0,05)}^{2}=12,592$ terdapat ada tiga outlier yang terdeteksi, yaitu data ke-30, 32 dan 33 dengan nilai $d_{M D}^{2}$ berturut-turut adalah 13,304; 16,789 dan 19,526. Karena terdapat outlier pada variabel independen, maka pada penelitian ini, analisis komponen utama dilakukan dengan dua cara, yaitu analisis komponen utama klasik dan analisis komponen utama robust.

\subsubsection{Analisis Komponen Utama Klasik}

Menghitung skor komponen utama dihitung dengan mengalikan variabel independen yang dalam hal ini adalah $\mathrm{Z}_{1}, \mathrm{Z}_{2}, \mathrm{Z}_{3}, \mathrm{Z}_{4}, \mathrm{Z}_{5}$, dan $\mathrm{Z}_{6}$ dengan eigenvector dari komponenkomponen utama yang terpilih. Sehingga diperoleh persamaan sebagai berikut:

$\mathrm{K}_{1}=0,39474 \mathrm{Z}_{1}-0,47476 \mathrm{Z}_{2}-0,47137 \mathrm{Z}_{3}-0,44252 \mathrm{Z}_{4}-0,32179 \mathrm{Z}_{5}+0,31181 \mathrm{Z}_{6}$ $\mathrm{K}_{2}=-0,47445 \mathrm{Z}_{1}-0,04226 \mathrm{Z}_{2}-0,03211 \mathrm{Z}_{3}-0,32629 \mathrm{Z}_{4}-0,57994 \mathrm{Z}_{5}-0,57383 \mathrm{Z}_{6}$

\subsubsection{Analisis Komponen Utama Robust}

Skor komponen utama dihitung dengan mengalikan variabel independen yang dalam hal ini adalah $\mathrm{Z}_{1}, \mathrm{Z}_{2}, \mathrm{Z}_{3}, \mathrm{Z}_{4}, \mathrm{Z}_{5}$, dan $\mathrm{Z}_{6}$ dengan eigenvector dari komponen-komponen utama yang terpilih. Sehingga diperoleh persamaan sebagai berikut:

$\mathrm{W}_{1}=0,42006 \mathrm{Z}_{1}-0,47816 \mathrm{Z}_{2}-0,41548 \mathrm{Z}_{3}-0,47326 \mathrm{Z}_{4}-0,31462 \mathrm{Z}_{5}+0,31514 \mathrm{Z}_{6}$ $\mathrm{W}_{2}=-0,51854 \mathrm{Z}_{1}-0,12876 \mathrm{Z}_{2}-0,13492 \mathrm{Z}_{3}-0,25135 \mathrm{Z}_{4}-0,53256 \mathrm{Z}_{5}-0,59121 \mathrm{Z}_{6}$

\subsubsection{Hasil Analisis Komponen Utama Klasik dan Analisis Komponen Utama Robust}

Tabel 3. Proporsi Kumulatif Varian AKU Klasik dan AKU Robust

\begin{tabular}{ccc}
\hline $\begin{array}{c}\text { Metode } \\
\text { Analisis }\end{array}$ & $\begin{array}{c}\text { Proporsi Kumulatif Varian } \\
\text { yang Dapat Dijelaskan }\end{array}$ & $\begin{array}{c}\text { Proporsi Kumulatif Varian } \\
\text { yang Tidak Dapat Dijelaskan }\end{array}$ \\
\hline AKU Klasik & $84,63 \%$ & $15,37 \%$ \\
AKU Robust & $90,52 \%$ & $9,48 \%$ \\
\hline
\end{tabular}




\subsection{Regresi Komponen Utama}

\subsubsection{Regresi Komponen Utama Klasik-OLS}

RKU Klasik-OLS adalah metode regresi yang mengkombinasikan AKU Klasik dengan analisis regresi menggunakan OLS, model RKU Klasik-OLS yang diperoleh adalah:

\subsubsection{Regresi Komponen Utama Robust-OLS}

$$
\widehat{\mathrm{Q}}=0,26562 \mathrm{~K}_{1}-0,45057 \mathrm{~K}_{2}
$$

RKU Robust-OLS adalah metode regresi yang mengkombinasikan AKU Robust dengan analisis regresi menggunakan OLS, model RKU Robust-OLS yang diperoleh adalah:

\subsubsection{Regresi Komponen Utama Klasik-(S-Estimator)}

$$
\widehat{\mathrm{Q}}=0,27839 \mathrm{~W}_{1}-0,48910 \mathrm{~W}_{2}
$$

RKU Klasik-(S-Estimator) adalah metode regresi yang mengkombinasikan AKU Klasik dengan analisis regresi menggunakan (S-Estimator), model RKU Klasik- ( $S$ Estimator) yang diperoleh adalah: $\widehat{\mathrm{Q}}=0,22176 \mathrm{~K}_{1}-0,29447 \mathrm{~K}_{2}$

\subsubsection{Regresi Komponen Utama Robust-(S-Estimator)}

RKU Robust-(S-estimator) adalah metode regresi yang mengkombinasikan AKU Robust dengan analisis regresi menggunakan S-estimator, model RKU Robust-(S-estimator) yang diperoleh adalah:

$$
\widehat{\mathrm{Q}}=0,23491 \mathrm{~W}_{1}-0,29548 \mathrm{~W}_{2}
$$

\subsection{Perbandingan Efektivitas Model Regresi Komponen Utama}

Perbandingan efektivitas keempat model regresi komponen utama (RKU) berdasarkan nilai Adjusted $\mathrm{R}^{2}$ dan Residual Standard Error (RSE) disajikan dalam Tabel 5 berikut:

Tabel 4. Perbandingan Efektivitas Model RKU Klasik-OLS, RKU Robust-OLS, RKU Klasik-(S-estimator), dan RKU Robust-(S-estimator)

\begin{tabular}{lcc}
\hline & Adjusted R $^{2}$ & RSE \\
\hline RKU Klasik-OLS & 0,5143 & 0,6869 \\
RKU Robust-OLS & 0,5730 & 0,6440 \\
RKU Klasik-(S-estimator) & 0,9135 & 0,4141 \\
RKU Robust-(S-estimator) & 0,9165 & 0,4073 \\
\hline
\end{tabular}

Dari Tabel 4 dapat dilihat bahwa model regresi komponen utama yang menerapkan metode robust MVE dan S-estimator, yaitu RKU Robust-(S-estimator) merupakan model yang paling efektif jika dibandingkan dengan ketiga model lainnya. Hal ini dikarenakan model tersebut mempunyai nilai Adjusted $\mathrm{R}^{2}$ yang paling besar yaitu 0,9165 dan nilai RSE yang paling kecil yaitu 0,4073 dengan model sebagai berikut:

$$
\widehat{\mathrm{Q}}=0,23491 \mathrm{~W}_{1}-0,29548 \mathrm{~W}_{2}
$$

Persamaan tersebut akan dikembalikan ke persamaan awal, sehingga diperoleh model RKU Robust-(S-estimator) sebagai berikut:

$$
\begin{gathered}
\widehat{Y}=8544,63619+53,79346 X_{1}-262,91108 X_{2}-750,33763 X_{3}-59,64477 X_{4} \\
+463,61536 X_{5}+0,00936 X_{6}
\end{gathered}
$$

\section{KESIMPULAN}

Dalam analisis regresi linier berganda dengan parameter OLS terdapat pelanggaran asumsi non multikolinieritas sehingga digunakan regresi komponen utama untuk penanganannya. Dalam penentuan komponen utama pada tahap analisis komponen utama digunakan pendekatan robust MVE untuk mengatasi pencilan. Sedangkan dalam tahap regresi komponen utama digunakan S-estimator untuk mengatasi pencilan dalam data. Setelah didapatkan beberapa model dibandingkan berdasarkan nilai Adjusted $R$-square dan RSE, diperoleh model terbaik yaitu Regresi Komponen Utama Robust-(S-Estimator): 


$$
\begin{gathered}
\widehat{Y}=8544,63619+53,79346 X_{1}-262,91108 X_{2}-750,33763 X_{3}-59,64477 X_{4} \\
+463,61536 X_{5}+0,00936 X_{6}
\end{gathered}
$$

Regresi Komponen Utama Robust S-Estimator menunjukan nilai Jumlah Pengangguran di Jawa Tengah dipengaruhi oleh jumlah penduduk Miskin $\left(\mathrm{X}_{1}\right), \operatorname{IPM}\left(\mathrm{X}_{2}\right)$, rata-rata lama sekolah $\left(\mathrm{X}_{3}\right), \operatorname{APM}\left(\mathrm{X}_{4}\right)$, APS $\left(\mathrm{X}_{5}\right)$ dan jumlah penduduk $\left(\mathrm{X}_{6}\right)$, sebesar $91,65 \%$ dan nilai RSE nya 0,4073 .

\section{DAFTAR PUSTAKA}

[BPS] Badan Pusat Statistik. 2018. Katalog Provinsi Jawa Tengah dalam Angka 2018. Jakarta : BPS.

Chen, C. 2002. Robust Regression and Outlier Detection with The ROBUSTREG Procedure, paper 265-27. SAS Instutute Inc., Lary, NC.

Draper, N.R. dan Smith, H. 1992. Analisis Regresi Terapan. Edisi Kedua. Diterjemahkan oleh : Bambang Sumantri. Jakarta : Gramedia Pustaka Utama. Terjemahan dari : Applied Regression Analysis.

Gujarati, D. N. 2004. Ekonometri Dasar. Diterjemahkan oleh : Sumarno Zain. Jakarta : Erlangga. Terjemahan dari : Basic Econometrics.

Johnson, R. A. dan Wichern, D. W. 2007. Applied Multivariate Statistical Analysis. Sixth Edition. New Jersey: Pearson Prentice Hall.

Kutner M. H., Nachtsheim, C. J., Neter, J., dan Li, W. 2005. Applied Linear Statistical Models. Fifth Edition. New York: The McGraw-Hill Companies, Inc.

Montgomery, D. C. dan Peck, E. A. 2012. Introduction To Linier Regression Analysis. Fifth Edition. New York: John Wiley and Sons, Inc.

Montgomery, D. C and Runger, G. C. 2011.Applied Statistics and Probability for Engineers :John Wiley \& Sons, Inc, USA

Neter, J., Wasserman, W., dan Kutner, M. H. 1988. Applied Linier Regression Model. USA : Richard D. Irwin. Inc.

Rousseeuw P. J. dan Aelst, S. V. 2009. Minimum Volume Ellipsoid. New York: John Wiley \& Sons, Inc.

Rousseeuw, P. J. dan Yohai, V. 1984. "Robust Regression by Means of S Estimators". Robust and Nonlinier Time Series Analysis, pp.256-272. New York : Springer Verlag.

Stuart, C. 2011. Robust Regression. England : Durham University. 